\title{
Spatial variability in the growth of invasive European barbel Barbus barbus in the River Severn basin, revealed using anglers as citizen scientists
}

\author{
Fatima Amat Trigo ${ }^{1,2}$, Catherine Gutmann Roberts ${ }^{1}$ and John Robert Britton ${ }^{1, *}$ \\ ${ }^{1}$ Faculty of Science and Technology, Bournemouth University, Poole BH12 5BB, UK \\ ${ }^{2}$ Departmento de Zoología y Antropología Física, Universidad de Murcia, Murcia, Spain
}

\begin{abstract}
Life history trait analyses of non-native fishes help identify how novel populations respond to different habitat typologies. Here, using electric fishing and anglers as citizen scientists, scales were collected from the invasive barbel Barbus barbus population from four reaches of the River Severn and Teme, western England. Angler samples were biased towards larger fish, with the smallest fish captured being $410 \mathrm{~mm}$, whereas electric fishing sampled fish down to $60 \mathrm{~mm}$. Scale ageing revealed fish present to over 20 years old in both rivers. Juvenile growth rates were similar across all reaches. Lengths at the last annulus and $L_{\text {infinity }}$ of the von Bertalanffy growth model revealed, however, that fish grew to significantly larger body sizes in a relatively deep and highly impounded reach of the River Severn. Anglers thus supplemented the scale collection and although samples remained limited in number, they provided considerable insights into the spatial demographics of this invasive B. barbus population.
\end{abstract}

Keywords: recreational fishery / invasion / non-indigenous / somatic growth

\begin{abstract}
Résumé - Variabilité spatiale de la croissance du barbeau européen invasif Barbus barbus dans le bassin de la rivière Severn, révélé en utilisant des pêcheurs comme des scientifiques citoyens. Les analyses des traits d'histoire de la vie de poissons non indigènes aident à identifier comment les populations nouvelles répondent à différentes typologies d'habitat. Ici, à l'aide de la pêche électrique et des pêcheurs à la ligne en tant que citoyens scientifiques, des écailles ont été recueillies sur des barbeaux, Barbus barbus, population envahissante de quatre tronçons des rivières Severn et Teme, dans l'ouest de l'Angleterre. Les échantillons des pêcheurs ont été orientés vers des poissons plus gros, le plus petit capturé étant de $410 \mathrm{~mm}$, tandis que la pêche électrique a échantillonné des poissons jusqu'à $60 \mathrm{~mm}$. La scalimétrie a révélé des poissons présents âgés de plus de 20 ans dans les deux rivières. Les taux de croissance des juvéniles étaient semblables dans tous les secteurs. Les longueurs au dernier annulus et le $L_{\text {infini }}$ du modèle de croissance de von Bertalanffy ont révélé, cependant, que le poisson atteint des tailles de corps significativement plus grandes dans un secteur relativement profond et fortement endigué de la rivière Severn. Les pêcheurs ont ainsi complété la collecte d'écailles et, bien que les échantillons soient restés limités en nombre, ils ont fourni des indications considérables sur la démographie spatiale de cette population invasive de $B$. barbus.
\end{abstract}

Mots-clés : pêche récréative / invasion / non autochtone / croissance somatique

The spatial analyses of life history traits of non-native fishes help predictions of the introduced species that will establish and develop invasive populations in new regions (Davies and Britton, 2015). These analyses also reveal the environmental conditions under which that species can thrive, for example their habitat preferences and thermal tolerances (Rahel and Olden, 2008). Traits such as somatic growth rates can show considerable variation over relatively small spatial

\footnotetext{
* Corresponding author: rbritton@bournemouth.ac.uk
}

scales, such as within catchments, especially where there has been considerable habitat disturbances caused by anthropogenic activity, such as impoundment (Rypel, 2011).

Invasive fishes are often associated with ecological impacts (Gozlan et al., 2010), although their populations can also support important recreational fisheries (Hickley and Chare, 2004). A strong example is the European barbel Barbus barbus where, in Britain, this cyprinid fish is only indigenous to eastern flowing rivers, but has now been introduced for angling into numerous rivers in their nonindigenous range (Wheeler and Jordan, 1990; Antognazza 




Fig. 1. Inset: Location of the study area within Great Britain. Main map: Locations of the upstream and downstream locations of each study reach $(\mathrm{R} 1-\mathrm{R} 4)$ on the Rivers Teme and Severn, where the upstream and downstream limits of reaches are marked with dashed lines. A number of important urban areas are also marked (filled circle).

et al., 2016). In the River Severn, western England, 509 adult fish were introduced in 1956 for fishery enhancement (Wheeler and Jordan, 1990). These fish established and dispersed throughout the middle and lower river, with reports in the 1970s of their capture by anglers in the River Teme, a major tributary of the Severn (Hunt and Jones, 1975; Wheeler and Jordan, 1990; Antognazza et al., 2016; Fig. 1). The species has since been an important component of angler catches in both rivers (North, 1980; North and Hickley, 1989; Britton et al., 2013). Whilst there was a series of studies completed on B. barbus invasion biology in the River Severn from samples collected in the 1960s (e.g. Hunt and Jones, 1975), there has been limited study of this population since (Britton et al., 2013). This is despite their presence over a wide range of physical habitats, ranging from narrow and shallow sections of the River Teme to impounded, deep and slow flowing sections of the lower Severn.

Citizen science approaches, where volunteers collect and/or process data as part of a scientific enquiry, are being increasingly applied to ecological research (Silvertown, 2009; Bonney et al., 2014), and have been used to supply fisheries data, including catch returns (Post et al., 2002; O’Neill and Faddy, 2003). More recent applications include non-lethal tissue sampling for genetics (Williams et al., 2015; Guindon et al., 2015) and stable isotope analysis (Bašić et al., 2015; Bašić and Britton, 2016). Given the frequent difficulty of obtaining ecological information on B. barbus in large rivers using regular sampling methodologies such as electric fishing (Britton et al., 2013), then the use of angling within data collection approaches could provide considerable benefit. Thus, the aim here was to analyse the spatial variability of the age and growth rates of invasive B. barbus in the Rivers Severn and Teme utilising scales collected by electric fishing and supplemented by angler catches.
Scales were collected from four reaches of the rivers between 2011 and 2016 (Fig. 1). The spatial separation of the reaches was based on the likelihood of $B$. barbus not moving between them. As adult $B$. barbus are highly vagile (Britton and Pegg, 2011) then each reach was at least $20 \mathrm{~km}$ in length (Fig. 1). Reach 1 was the furthest upstream reach in the River Teme, from a small weir at Ashford Carbonell $\left(52^{\circ} 20^{\prime} 07^{\prime \prime} \mathrm{N}\right.$; $\left.2^{\circ} 42^{\prime} 14^{\prime \prime} \mathrm{W}\right)$ to Stanford Bridge $\left(52^{\circ} 17^{\prime} 24^{\prime \prime} \mathrm{N} ; 2^{\circ} 25^{\prime} 14^{\prime \prime} \mathrm{W}\right)$ (Fig. 1). Reach 2 was the lower River Teme, from a weir at Knightwick $\left(52^{\circ} 11^{\prime} 57^{\prime \prime} \mathrm{N} ; 2^{\circ} 23^{\prime} 22^{\prime \prime} \mathrm{W}\right)$ to upstream of a weir of Powick $\left(52^{\circ} 10^{\prime} 11^{\prime \prime} \mathrm{N} ; 2^{\circ} 14^{\prime} 49^{\prime \prime} \mathrm{W}\right)$. This weir was used as barrier between Reach 2 and 3 as an ongoing tracking study on $B$. barbus suggested it is largely impassable except under high water conditions (C. Gutmann Roberts, unpublished data). Reach 3 started downstream of this weir and continued into the lower River Severn between Diglis Weir $\left(52^{\circ} 10^{\prime} 45^{\prime \prime} \mathrm{N}\right.$; $\left.2^{\circ} 13^{\prime} 34^{\prime \prime} \mathrm{W}\right)$ and Upper Lode Weir $\left(51^{\circ} 99^{\prime} 41^{\prime \prime} \mathrm{N} ; 2^{\circ} 10^{\prime} 13^{\prime \prime} \mathrm{W}\right)$, as the tracking study mentioned above revealed $B$. barbus frequently move between both rivers. Reach 4 was in the middle River Severn, between Bridgnorth $\left(52^{\circ} 31^{\prime} 37^{\prime \prime} \mathrm{N}\right.$; $2^{\circ} 25^{\prime} 03^{\prime \prime} \mathrm{W}$ ) and Arley ( $\left.52^{\circ} 24^{\prime} 27^{\prime \prime} \mathrm{N} ; 2^{\circ} 20^{\prime} 49^{\prime \prime} \mathrm{W}\right)$ (Fig. 1). The physical, flow and chemical parameters of each Reach are provided in Table 1.

Electric fishing was completed in Reach 3 on September 22nd, 2015 from Powick Weir downstream for $500 \mathrm{~m}$, with Reach 1 and 2 electric fished in September 2016. Reach 4 was unable to be electric fished during the study. Following their capture, fish were measured (fork length, nearest $\mathrm{mm}$ ), and 3-5 scales removed and placed into a paper envelope before the fish were returned to the river. Regarding angling, the Environment Agency has trained a small number of catch-and-release anglers in the River Severn catchment to measure captured fish and collect scale samples in order to assist their fisheries 
F.A. Trigo et al.: Knowl. Manag. Aquat. Ecosyst. 2017, 418, 17

Table 1. Sample sizes by study reach and their altitude (as metres above sea level, MSL), river flow (as $Q$ values, $\mathrm{m}^{3} \mathrm{~s}^{-1}$; CEH, 2016), and average score per taxon (ASPT, as a measure of biological water quality), mean concentrations of ammonia $\left(\mathrm{mg} \mathrm{N} \mathrm{L}^{-1}\right)$, nitrate $\left(\mathrm{mg} \mathrm{L}^{-1}\right)$ and phosphates $\left(\mathrm{mg} \mathrm{L}^{-1}\right)$ in 2009 (Environment Agency, 2009).

\begin{tabular}{lllrrrrrrrrr}
\hline Reach & $n$ & MSL $(\mathrm{m})$ & \multicolumn{1}{c}{$Q_{10}$} & \multicolumn{1}{c}{$Q_{50}$} & \multicolumn{1}{c}{$Q_{95}$} & ASPT & $\mathrm{NH}_{3}$ & Nitrates & Phosphates & Mean width & Mean depth (m) \\
\hline 1 & 37 & 48 & 34.9 & 8.3 & 1.6 & 6.1 & 0.05 & 20.9 & 0.05 & 15 & 1.0 \\
2 & 98 & 21 & 42.1 & 10.1 & 2.0 & 6.0 & 0.03 & 20.1 & 0.06 & 15 & 1.0 \\
$3^{*}$ & 88 & 8 & 219.0 & 53.6 & 15.4 & 4.9 & 0.06 & 22.0 & 0.24 & 35 & 4.0 \\
4 & 18 & 17 & 146.5 & 36.5 & 10.7 & 5.8 & 0.04 & 17.4 & 0.14 & 25 & 2.0 \\
\hline
\end{tabular}

* Data presented for the River Severn section of the reach, rather than the River Teme (Fig. 1).

management activities. Correspondingly, scales were available for angler captured B. barbus from each reach. Note these sampling methods did not allow for the sexing of individual fish and so this was unable to be accounted for in subsequent testing of data.

Scales were aged on a projecting microscope, with ageing errors minimised by application of a quality control (QC) procedure (Musk et al., 2006). In the QC, agreement in ages between readers were generally above $80 \%$ for fish up to the age of 15 years but were reduced thereafter (48-74\%). Thus, in subsequent analyses, only fish to age 15 years were used. Scales were measured for scale radius, distance to last annulus and distance between annulus 1 and 2, with these converted to length at the last annulus and length increment between age 1 and 2 years old by back-calculation (Dahl Lea method; Francis, 1990). Length at the last annulus enabled growth rates over the life time of the fish to be assessed, whilst the increment between age 1 and 2 years enabled assessment of juvenile growth rates (Beardsley and Britton, 2012). Differences in the lengths of the fish sampled by angling and electric fishing were tested using a generalised linear model (GLM), as these data were not normally distributed, with the significance of differences assessed by linearly independent pairwise comparisons with Bonferroni adjustment for multiple comparisons.

The growth data were analysed by two different methods. Firstly, analyses determined the mean standardized growth residuals for each reach according to lengths at the last annulus and length increment between age 1 and 2 years (Beardsley and Britton, 2012). Only one growth metric value per fish was used in each test to avoid pseudo-replication (Beardsley and Britton, 2012). For length at the last annulus, length at age data for all reaches and fish (age 1-15 only) were used in the log-log quadratic function of Vilizzi and Walker (1999) to determine the mean length at each age. This enabled the standardized residual of each individual fish to be calculated (Beardsley and Britton, 2012), with these then tested between the four reaches using a generalized linear model. Outputs were the mean standardized residuals per reach and the significance of the difference between them according to linearly independent pairwise comparisons with Bonferroni adjustment for multiple comparisons. The same method was then applied to the length increment between age 1 and 2 data, using the mean length increment over the four reaches to determine the standardized residual for each fish. Secondly, the von Bertalanffy growth model was applied to data from each reach to provide values of $L_{\text {infinity }}$ and the growth coefficient $(K)$. This used a two-parameter model of the form: $L_{t}=L_{\text {infinity }}\left(1-\exp ^{-K t}\right)$, where $L_{t}$ was the actual length of each fish at observed age $t, L_{\text {infinity }}$ was the asymptotic length (i.e. maximum theoretical body size for the population) and $K$ was the growth coefficient (i.e. its annual growth rate to $L_{\text {infinity, }}$ referred to hereafter as the growth rate) and fitted using a nonlinear minimization of the negative log-likelihood of the form: $-\ln =n \ln \sigma+n / 2$, where $\sigma=\sqrt{ } \sum \frac{\left(L i-L^{\prime} i\right)^{2}}{n}$, where $L i, L^{\prime} i$ and $n$ are the respective observed and predicted lengths-at-age, and the number of fish, and provided estimates of each parameter and their $95 \%$ confidence limits.

There were 241 fish captured in the study, with the majority captured from Reaches 2 and 3 in 2015 and 2016 (Tab. 1). The length range of fish captured by anglers was $410-800 \mathrm{~mm}$ $(n=159$; mean: $599 \pm 22 \mathrm{~mm})$ and by electric fishing was 60-770 mm ( $n=82$; mean $423 \pm 30 \mathrm{~mm}$ ) (Fig. 2), with these length differences significant (GLM: Wald $\chi^{2}=86.10$, $P<0.01)$. Individual fish were aged to at least 20 years old. As fish $>15$ years old were omitted from growth rate analyses and some fish were unable to be aged due to all collected scales being regenerated, 189 fish were actually utilised in subsequent analyses.

At the individual level, there was considerable variability in the lengths at the last annulus by age (Fig. 3A), with a significant relationship between reach and the mean standardised growth residuals of lengths at the last annulus (GLM: Wald $\chi^{2}=32.98, P<0.01$; Fig. 3B). There was no significant difference between these residuals for Reach 1 and 2, or 3 and 4 , but differences were significant between Reach $1 / 2$ versus $3 / 4(P<0.01$; Fig. 3B). In contrast, the relationship between reach and the mean standardised growth residuals for the increment between age 1 and 2 revealed no significant differences (GLM: Wald $\chi^{2}=3.08, P=0.38$; Fig. 3C). The $95 \%$ confidence limits of $L_{\text {infinity }}$ of the von Bertalanffy growth model in Reach 3 were significantly and substantially higher than the other reaches (95\% confidence limits Reach 3: 821-828 mm, other reaches: $690-729 \mathrm{~mm}$ ). For $K$, there were no significant differences between Reach 1 and $2(0.12-0.15)$, and 3 and 4 (0.09-0.11).

These results indicate that the scales contributed by recreational anglers to this study enabled significant differences in the spatial patterns of invasive $B$. barbus growth in this river sub-catchment to be revealed. Moreover, these scales would have been otherwise extremely difficult to collect by alternative methods, either due to fast flows and 

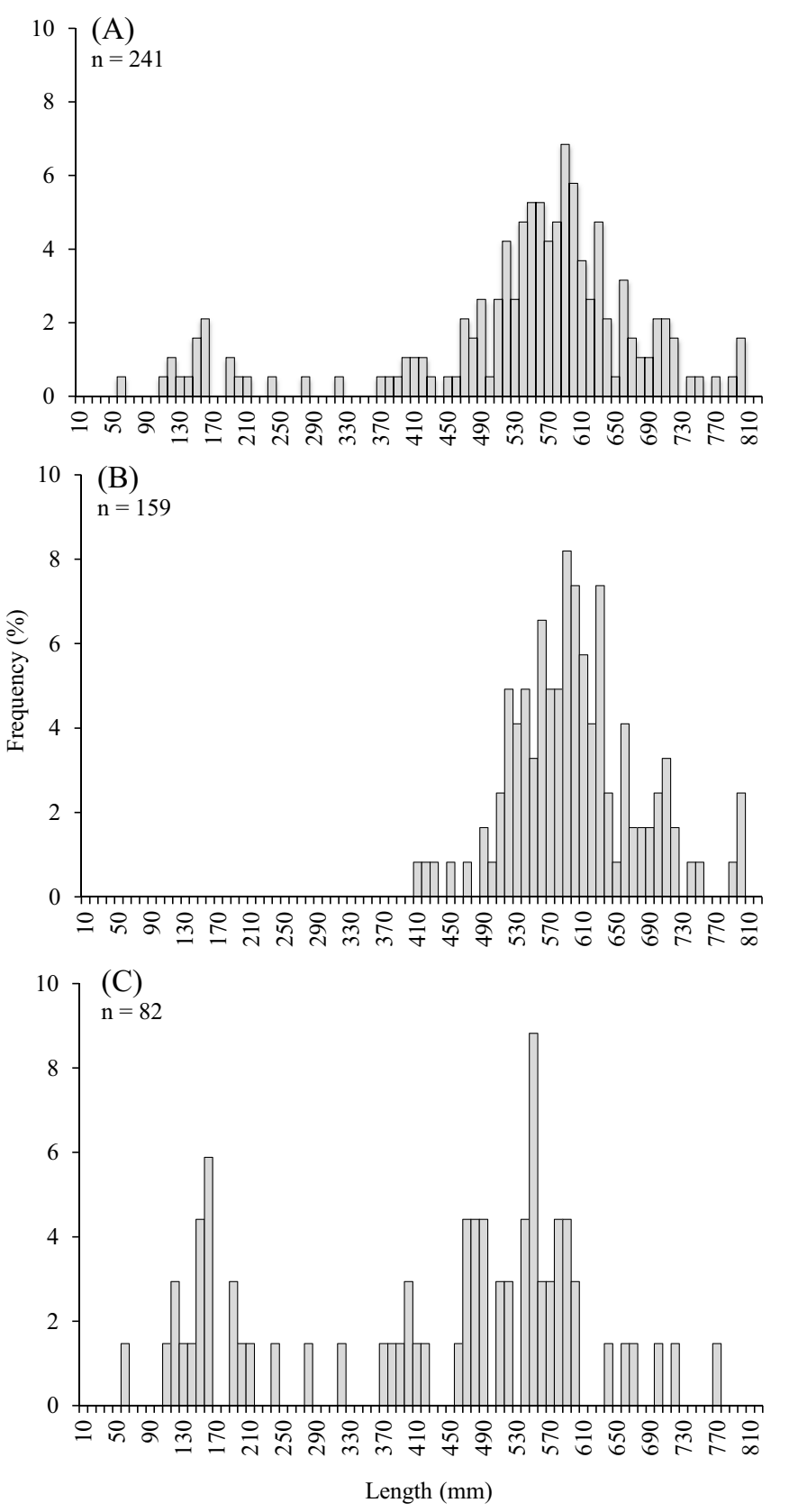

Fig. 2. Length frequency histograms of: (A) all Barbus barbus sampled within this study from all reaches $(n=259)$; (B) B. barbus sampled by angling; and (C) B. barbus sampled by electric fishing.

shallow water (Reach 1 and 2), or very deep water (Reach 4). However, the angler catches were heavily biased towards larger fish and also resulted in relatively small sample sizes. This is important, as studies on the precision of age and growth data have suggested that, in Argyrozona argyrozona, 10 fish per $20 \mathrm{~mm}$ increments should be collected for high precision (Brouwer and Griffiths, 2005) and for the cyprinid fishes Rutilus rutilus, Squalius cephalus and Leuciscus leuciscus, Busst and Britton (2014) suggested precision of growth data was highest when samples comprised at least 10 fish per $5 \mathrm{~mm}$ increment. In the latter study, however, the fishes concerned are all relatively abundant in many lowland
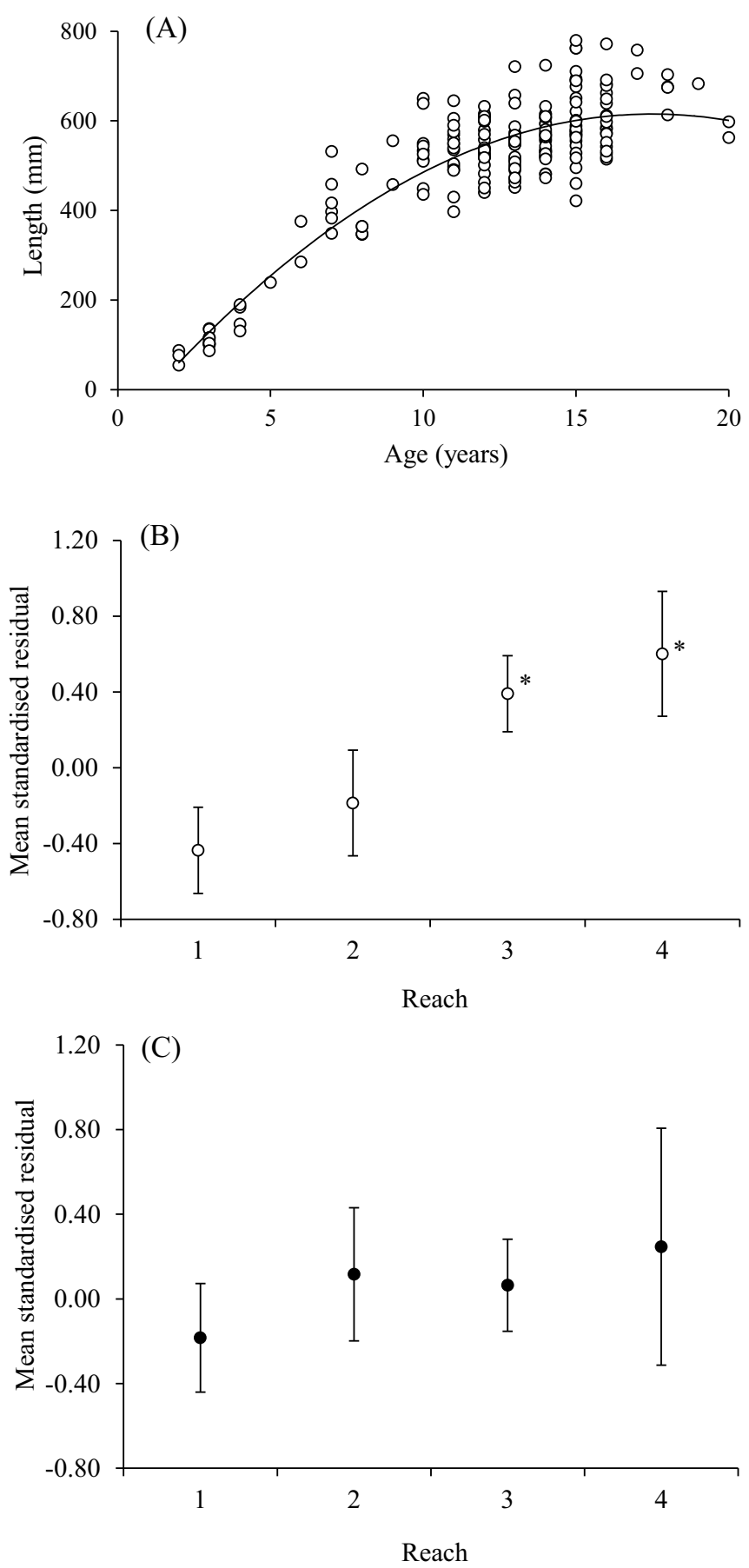

Fig. 3. (A) Lengths at last annulus by age of Barbus barbus across the study sites (clear circles) and the modelled length at age (black line); (B) mean standardised growth residuals from length at last annulus per study reach, where ${ }^{*}$ denotes difference of the mean for that reach is significantly different to Reach 1 according to pairwise comparisons in the generalised linear model $(P<0.01)$; and $(C)$ mean standardised growth residuals from length increment between age 1 and 2 years.

rivers, with electric fishing and angling both generally able to provide samples capable of complying with these sub-sample requirements. In contrast, B. barbus is a large bodied cyprinid with riverine populations that are far less abundant than many other species. Although Hunt and Jones (1975) did utilise 
much larger numbers of $B$. barbus in their age and growth study on Reach 4 in the 1960s, using both electric fishing and angling, this was during a period of rapid population expansion following their introduction, with large numbers of small B. barbus $(<350 \mathrm{~mm})$ captured by angling. In the current study, these size classes were absent from angler catches and proved very difficult to obtain by electric fishing. Thus, the limited sample sizes of the current study are a potential concern in terms of the precision of the growth data and so should be treated with some caution, but with the caveat that supplementing these samples with greater numbers of fish would be highly challenging.

Despite these inherent issues with sample sizes and fish lengths, the scale samples indicated that individual fish were present in the rivers to at least 20 years old, and potentially older given the inherent difficulties of ageing of large, slow growing B. barbus from scales (Britton and Pegg, 2011; Britton et al., 2013). The growth data then indicated that differences in the growth rates of the fish between the reaches were primarily in relation to their adult growth and ability to grow to large body sizes. This suggests that across the four reaches, there were sufficient juvenile habitat and food resources but, thereafter, there was some variability in growth rates, with Reach 3 having fish with the highest $L_{\text {infinity }}$ and lowest $k$ values, where the river is impounded and relatively deep, with the only areas of fast flowing, shallow, riffle areas being in the lower River Teme and in a weir pool. Despite this contrast with typical B. barbus habitat (Huet, 1959; Britton and Pegg, 2011), the largest $B$. barbus captured from the river also tend to be captured from this reach, with individuals up to almost $8 \mathrm{~kg}$ in mass. Comparison of the von Bertalanffy growth parameters here to the estimates of Hunt and Jones (1975) also suggested that the fish in the river today grow to substantial larger body sizes but at a slower annual growth rate than in the 1960s. However, these comparisons are only really valid for Reach 4 , where the Hunt and Jones (1975) study was completed, and where the sample size for 2011-2016 was very low.

In summary, recreational anglers provided scale samples that had high utility in assessing spatial variability in the growth rates of this invasive $B$. barbus population and revealed the largest individuals were present in the lower impounded section of the River Severn. The results also suggested that when angling is applied to obtain data in this manner, caution is required in relation to the size ranges of fishes they exploit and the sample sizes they can provide.

Acknowledgements. The study was funded by the Severn Rivers Trust, with support from the Environment Agency and the Barbel Society. We particularly wish to thank Mr. Pete Reading of the Barbel Society and all anglers who contributed to the scale collection, and Mr. Brecht Morris who organised the electric fishing.

\section{References}

Antognazza CM, Andreou D, Zaccara S, Britton JR. 2016. Loss of genetic integrity and biological invasions result from stocking and introductions of Barbus barbus: insights from rivers in England. Ecol Evol 6: 1280-1292.
Bašić T, Britton JR. 2016. Characterising the trophic niches of stocked and resident cyprinid fishes: consistency in partitioning over time, space and body sizes. Ecol Evol 6: 5093-5104.

Bašić T, Britton JR, Jackson MC, Reading P, Grey J. 2015. Angling baits and invasive crayfish as important trophic subsidies for a large cyprinid fish. Aquat Sci 77: 153-160.

Beardsley H, Britton JR. 2012. Contribution of temperature and nutrient loading to growth rate variation of three cyprinid fishes in a lowland river. Aquat Ecol 46: 143-152.

Bonney R, Shirk JL, Phillips TB, et al. 2014. Next steps for citizen science. Science 343: 1436-1437.

Britton JR, Pegg J. 2011. Ecology of European barbel Barbus barbus: implications for river, fishery, and conservation management. Fish Sci 19: 321-330.

Britton JR, Davies GD, Pegg J. 2013. Spatial variation in the somatic growth rates of European barbel Barbus barbus: a UK perspective. Ecol Freshw Fish 22: 21-29.

Brouwer SL, Griffiths MH. 2005. Influence of sample design on estimates of growth and mortality in Argyrozona argyrozona (Pisces: Sparidae). Fish Res 74: 44-54.

Busst GM, Britton JR. 2014. Precision of the age-length increments of three cyprinids: effects of fish number and sub-sampling strategy. J Fish Biol 84: 1926-1939.

CEH. 2016. National River Flow Archive. http://nrfa.ceh.ac.uk/ (last accessed 2016/29/11).

Davies GD, Britton JR. 2015. Influences of population density, temperature and latitude on the growth of invasive topmouth gudgeon Pseudorasbora parva. Ecol Freshw Fish 24: 91-98.

Environment Agency. 2009. River Quality. http://maps.environmentagency.gov.uk/wiyby/dataSearchController?lang=_eandtextonly= offandtopic=riverquality (last accessed 2016/27/11).

Francis RICC. 1990. Back-calculation of fish length: a critical review. J Fish Biol 36: 883-902.

Gozlan RE, Britton JR, Cowx IG, Copp GH. 2010. Current knowledge on non-native freshwater fish introductions. $J$ Fish Biol 76: 751-786.

Guindon K, Neidig C, Tringali M, et al. 2015. An overview of the tarpon genetic recapture study - a citizen science success story. Environ Biol Fishes 98: 2239-2250.

Hickley P, Chare S. 2004. Fisheries for non-native species in England and Wales: angling or the environment? Fish Manag Ecol 11: 203-212.

Huet M. 1959. Profiles and biology of western European streams as related to fish management. Trans Am Fish Soc 88: 155-163.

Hunt PC, Jones JW. 1975. A population study of Barbus barbus L. in the River Severn, England. J Fish Biol 7: 361-376.

Musk RS, Britton JR, Axford S. 2006. The effect of subjective fish scale ageing on growth and recruitment analyses: a case study from the UK. Acta Ichthyol Piscat 36: 81-84.

North E. 1980. The effects of water temperature and flow upon angling success in the River Severn. Aquac Res 11: 1-9.

North E, Hickley P. 1989. An appraisal of anglers' catches in the River Severn, England. J Fish Biol 34: 299-306.

O'Neill MF, Faddy MJ. 2003. Use of binary and truncated negative binomial modelling in the analysis of recreational catch data. Fish Res 60: 471-477.

Post JR, Sullivan M, Cox S, et al. 2002. Canada's recreational fisheries: the invisible collapse? Fisheries 27: 6-17.

Rahel FJ, Olden JD. 2008. Assessing the effects of climate change on aquatic invasive species. Conserv Biol 22: 521-533.

Rypel AL. 2011. River impoundment and sunfish growth. Riv Res Appl 27, 580-590. 
F.A. Trigo et al.: Knowl. Manag. Aquat. Ecosyst. 2017, 418, 17

Silvertown J. 2009. A new dawn for citizen science. Trend Ecol Evol 24: 467-471.

Vilizzi L, Walker K. 1999. Age and growth of the common carp, Cyprinus carpio, in the River Murray, Australia: validation, consistency of age interpretation, and growth models. Environ Biol Fishes 54: 77-106.
Wheeler A, Jordan DR. 1990. The status of the barbel, Barbus barbus (L.) (Teleostei, Cyprinidae), in the United Kingdom. J Fish Biol 37: 393-399.

Williams SM, Holmes BJ, Pepperell JG. 2015. The novel application of non-lethal citizen science tissue sampling in recreational fisheries. PLOS ONE 10: e0135743.

Cite this article as: Trigo FA, Gutmann Roberts C, Robert Britton J. 2017. Spatial variability in the growth of invasive European barbel Barbus barbus in the River Severn basin, revealed using anglers as citizen scientists. Knowl. Manag. Aquat. Ecosyst., $418,17$. 